\section{Hvorfor har så mange jøder vunnet nobelprisen?}

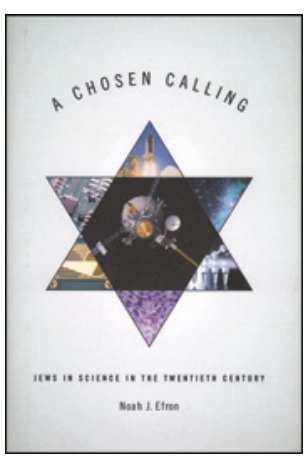

\section{Noah J. Efron}

\section{A chosen calling}

Jews in science in the twentieth century. $149 \mathrm{~s}$.

Baltimore, MD: The Johns Hopkins University

Press, 2014. Pris USD 27

ISBN 978-1-4214-1381-5

Jøder har gjennom tidene bidratt sterkt til intellektuelt og vitenskapelig liv i Europa. Den norskamerikanske sosiologen Torstein Veblen (1857-1929) publiserte i 1919 en artikkel der han diskuterte årsaken (1). Han har ikke vært den siste som har søkt en forklaring. Det er ikke overraskende, for tallenes tale er overveldende. Utviklingen har vært mer dramatisk enn Veblen kunne forutsagt. Av nobelpristakerne i medisin i perioden 1901-2014 har totalt $27 \%$ jødisk bakgrunn, og $39 \%$ av dem fra USA. Tilsvarende tall for fysikk er henholdsvis $26 \% \operatorname{og} 37 \%$, og for kjemi $21 \% \operatorname{og~} 32 \%$. De vanligste forklaringene har vært at det enten skyldes genetikk, jøder er spesielt begavet, eller den måten troende jøder læres opp fra barnsbein av.

Mot disse forklaringene stiller Noah Efron, som er forsker og underviser på Bar-Ilan-universitetet $i$ Israel, opp et annet sett hypoteser. Han tar utgangspunkt i den migrasjon som preget det 20. århundrets jøder. Forfatterens eksempler er fra de stedene der denne migrasjonen var mest uttalt, til USA, fra landsbygda i Russland til byer i Sovjetunionen og til Palestina. Efron avviser genetiske hypoteser, og at det er noe spesielt i jødisk opplæring som gir en fordel i naturvitenskapelig arbeid, men mener at jødenes innsats innenfor de teknisk-naturvitenskapelige fag i USA, Sovjet og Palestina først og fremst hadde andre sosiologiske og historiske årsaker. Han argumenterer godt for hvordan disse fagene var like mye et middel som et mål i tilpasningen til storsamfunnet rundt dem. For den enkelte ofte et mål, for gruppen et overordnet middel.

Selv synes jeg kapitlene om jødene i USA og Sovjet er de mest interessante, skildringene av ned- og oppturene begge steder er god og tankevekkende kultur- og vitenskapshistorie. Men også naturvitenskapens plass i det Efron kaller «[the] Zionist imagination and enterprise» gir grunn til ettertanke.

Boken er ikke lettlest. Det skyldes ikke det store noteapparatet, 37 sider til en tekst på 105 sider. Dette gir fin tilleggsinformasjon og kan med fordel leses etter hovedteksten. Efrons språk krever imidlertid stor konsentrasjon, dette er ikke populærhistorie. Av og til må leseren bruke øks for å komme gjennom språk og argumentasjon.

Det er det verdt. Denne spennende og stimulerende boken anbefales til kolleger som er interessert ikke bare i vitenskapshistorie, men også i 1900-tallets kulturhistorie mer generelt.

\section{Per E. Børdahl}

Pensjonert klinikkoverlege, Høvik

\section{Litteratur \\ 1. Veblen T. The intellectual pre-eminence of Jews in modern Europe. Political Science Quarterly 1919; 34: 33-42. www.jstor.org/stable/2141518 (29.11.2014).}

\section{Er det for mange av oss?}

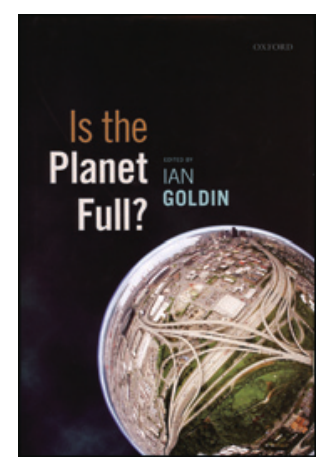

Ian Goldin, red.

Is the planet full?

245 s, tab, ill. Oxford: Oxford University Press,

2014. Pris GBP 30

ISBN 978-0-19-967777-1

Da jeg gikk på gymnasiet i 1953, leverte jeg inn en stil med et selvvalgt emne som var nokså likt denne boktittelen. Min norsklærer skrev i sin kommentar: «Det må da være grenser for dysterhet, Anton.» I 1953 var det 2,53 milliarder mennesker på jorden. Nå er det over 7 milliarder. Jeg var derfor interessert i å se hvor mye dysterhet som preget de ti forfatterne av denne boken. Vel, det var mindre enn jeg hadde ventet. Flere pekte på at befolkningsøkning kan føre til mer innovasjon, flere metoder for å produsere mer mat, flere oppfinnelser som bedrer menneskenes livskvalitet, og nye talenter som vil gi oss enestående kunstverk og musikk. Det er besnærende tanker, men ville det ikke vært bedre først å sørge for at de som allerede er til stede, får utdanning? Ikke minst kvinner. Og ville det ikke også vært bedre først å sørge for at de to milliarder mennesker som er feilernærte eller underernærte, blir hjulpet før vi satser på ufødte genier? Men for å få til slike omfattende løsninger må menneskene samarbeide. Ett av kapitlene i boken handler om dette. Svikten i lederskap på globalt nivå kan tilbakeføres til nasjonenes manglende fokus på de kritiske spørsmål om ressursbruk og håndtering av fellesgoder som følger av økende tetthet. Det reflekterer nasjonenes valg av ledere som har liten interesse for slike spørsmål.

Denne bokens ti forfattere er akademikere knyttet til University of Oxford. De behandler et bredt spekter av temaer som naturlig hører med i en analyse av de utfordringene menneskeheten vil stå overfor når folketallet fortsetter å øke, kanskje til 12 milliarder. Spørsmålet i boktitlen omtales bl.a. i lys av etikk, fysikk, økonomi, geopolitikk, jordbruk og medisin. De enkelte kapitlene kan leses som frittstående essays, for eksempel kapitlene om vanntilførsel, ernæring og mineralforbruk, samt om ulikheter mellom nasjoner og innenfor nasjoner. Redaktøren, Ian Goldin, har skrevet et lengre sammenbindende og løsningsorientert kapittel. Han ser på denne boken som en oppfølger av verket Limits to growth, som ble publisert i 1972. De scenarier som ble kvantetisert og fremskrevet den gang, stemte ganske godt med utviklingen frem til år 2000. Forhold som ikke kunne ha vært forutsett, men som omtales i denne nye boken, er den sterke utviklingen innenfor datateknologi, genmodifisert mat og utslipp av drivhusgasser til atmosfæren. Den store ukjente variabelen er stadig menneskers uberegnelige atferd.

Dette er en velskrevet og tankevekkende bok. Kanskje den kan bidra til å høyne nivået på politiske debatter - og beslutninger. Det er et pluss at forfatterne har tilstrebet kvantitative utsagn og ikke løsaktige påstander. Det jeg kan savne, er en nærmere omtale av den virkning vi mennesker har på andre liv enn våre egne. Ved å ignorere dette spørsmålet kan vi få noen ubehagelige overraskelser lenger frem i tid.

\section{Anton Hauge}

Professor emeritus i fysiologi, Universitetet i Oslo 